\title{
True Nature of Supply Network Communication Structure
}

\author{
Lokhman Hakim bin Osman \\ School of Management, Universiti Kebangsaan Malaysia, 43600 UKM, Selangor, Malaysia
}

ART I C LE INFO

Keywords:

Supply Chain Management,

Network Studies,

Inter-Organizational Relations,

Social Capital

\section{A B S T RAC T}

Globalization of world economy has altered the definition of organizational structure. Global supply chain can no longer be viewed as an arm-length structure. It has become more complex. The complexity demands deeper research and understanding. This research analyzed a structure of supply network in an attempt to elucidate the true structure of the supply network. Using the quantitative Social Network Analysis methodology, findings of this study indicated that, the structure of the supply network differs depending on the types of network relations. An important implication of these findings would be a more focus resource management upon network relationship development that is based on firms' positions in the different network structure. This research also contributes to the various strategies of effective and efficient supply chain management.

\section{SARI PATI}

Globalisasi ekonomi dunia telah mengubah definisi struktur organisasi. Rantai pasokan global tidak bisa lagi dipandang sebagai arm-length structure, namun menjadi lebih kompleks. Kompleksitas tersebut menuntut penelitian dan pemahaman lebih dalam. Peneliti menganalisis struktur jaringan pasokan dalam upaya menjelaskan struktur yang benar dari jaringan pasokan. Dengan menggunakan metodologi analisis jaringan sosial, penelitian ini menunjukkan bahwa struktur jaringan pasokan berbeda tergantung pada jenis hubungan jaringan. Implikasi penting dari temuan ini akan menjadi referensi pengelolaan sumber daya yang lebih berfokus pada hubungan jaringan pembangunan berdasarkan posisi perusahaan dalam jaringan yang berbeda struktur. Penelitian ini juga berkontribusi untuk berbagai strategi manajemen rantai pasokan yang efektif dan efisien. 


\section{INTRODUCTION}

In the early 1980 the focused of many scholarly works centered on understanding the integration of business processes throughout the supply chain (Ragatz, Handfield and Petersen, 2002; Vyas and Woodside, 1984; Zenger and Lawrence, 1989). Emphasis was given on the structure of the supply chain in order to deliver goods and services that meet the end users' needs. Scholars then began to integrate different frameworks and views of SCM and, thereby, better define the domain of Supply Chain Management (SCM). As a result, several frameworks have been developed to guide research and practice (Carbonara, Giannoccaro and Pontrandolfo, 2002; Kersten et al., 2006; Peck, 2005; Perona and Miragliotta, 2004; Piramuthu, 2005) SCM research has since evolved to encompass a combination of trends in the management literature, such as industrial markets, integrated materials' management, system integration, the "quality" revolution, management of relationships, and business process integration and management.

Despite the varying and progressive perspective of the supply chain, each of the notions of the supply chain management relies on terms such as coordination and integration and emphasizes the harmonization of operation among organizations in the supply chain (Bowersox, Closs and Cooper, 2002). In addition, the focus of this early conceptualization of the supply chain directed on their cross-functional business processes with the objective of providing value for the entire supply chain (Lambert and Cooper, 2000; Lambert, Cooper and Pagh, 1998)

These days, supply chain management (SCM) involves adapting to changes in a complicated and complex global network of organizations (Choi and Krause, 2006; Hoole, 2004; Li et al., 2010; Masson et al., 2007; Sivadasan et al., 2010; Sivadasan et al., 1999; Vickers and Kodarin, 2006; Zhou, 2005). Since the early 2000 , scholarly work began to conceptualize supply chain as supply network to better illuminate the complexity of the organizations' inter connectivity (Harland et al., 2001; Lamming et al., 2000). For example, researchers have confirmed the existence of informal network structure on top of the formal network structure that formed a supply chain (Choi 2010, Osman 2013). A typical supply network consists of inter firm relationships that may connect numerous industries. As a result, supply chain management often requires consideration of a large number of factors from various dimensions and perspectives. Managing the complex upstream supply network can be a difficult task for managers of the supply chain. The traditional reductionist arguments state that firms opted for the removal from the complex upstream supply chain of partners who are not meeting the performance requirements of the supply chain in an attempt to manage the complexity arising from extensive inter-firm relationships (Choi and Kim, 2008). However, recent arguments suggest that simply removing these underperforming firms may not be the best way, as firms may remove partners who are resourceful or more influential, but these characteristics are not visible through good accounting measures. Thus this research embark on goal to better understand the actual structure of the supply chain as this will eventually help operationalization of resources.

\section{Literatur Review}

It is important to note that the supply chain is no longer a chain. It is a network of inter- connected firms. Oliver and Weber (1982) are believed to be among the first scholars to use the term supply chain to describe the flow of resource and materials from the suppliers to the end users. In the early 1980 the focused of many scholarly works centered on understanding the integration of business processes throughout the supply chain (Ragatz, Handfield and Petersen, 2002; Vyas and Woodside, 1984; Zenger and Lawrence, 1989). Emphasis was given on the structure of the supply chain in order to deliver goods and services that meet the end users' needs. Scholars 
then began to integrate different frameworks and views of SCM and, thereby, better define the domain of Supply Chain Management (SCM). As a result, several frameworks have been developed to guide research and practice (Carbonara, Giannoccaro and Pontrandolfo, 2002; Kersten et al., 2006; Peck, 2005; Perona and Miragliotta, 2004; Piramuthu, 2005) SCM research has since evolved to encompass a combination of trends in the management literature, such as industrial markets, integrated materials' management, system integration, the "quality" revolution, management of relationships, and business process integration and management.

Antecedents of Supply Network. Over the years, various structures of the supply chain have evolved. One important finding of Womack (1990) is that, in a supply chain, the exchanges between the firms not only concern the formal exchanges of materials from the upstream suppliers to the downstream customers. Most importantly, it also involves informal forms of relations such as other commercial transactions, including information-sharing and referral activities, which create a significant competitive advantage to the firms embedded in such relationship structures (Lazzarini, 2000; Borgatti and Lie, 2010). Choi and Krause (2001) study the flow of materials in three automobile manufacturers in North America. The authors mapped the network of flow of parts and materials for the assembly of the center console for several models. Base on the mapping of the network, it shows that the flows of materials are not linear as commonly perceived. Furthermore, in a supply network of the center console parts and materials, it could be assumed that the other organizations or suppliers in the supply network are connected to other organizations through some indirect connections. This indirect connectivity could mean that organizations in the supply network are communicating with each other without the knowledge of the other organizations or suppliers.
This seminal work of Choi and Krause (2001) has led to other further analysis. Lazzarini (2002) study tried to visualize the adoption of the social network concepts for the supply network study using what is termed net chain analysis. The authors conclude that a supply network consists of a number of hierarchical layers, and each layer contains many other firms that are connected to other organizations in the network either through horizontal connections or vertical connections. Kim (2001) adopted the structural holes' concepts (structural holes relate to how an organization in a network can be connected or tie to other organizations in the network through indirect connections) to explain the flow of information in the supply network. Kim (2011) conceptualized several supply network concepts such as material supply using social network elements such as in-degree centrality to explain how materials flow from the upstream suppliers to the focal organizations in the supply network. Despite the varying and progressive perspective of the supply chain, each of the notions of the supply chain management relies on terms such as coordination and integration and emphasises the harmonization of operation among organizations in the supply chain (Bowersox, Closs and Cooper, 2002). In addition, the focus of this early conceptualization of the supply chain focus on their cross-functional business processes with the objective of providing value for the entire supply chain (Lambert and Cooper, 2000; Lambert, Cooper and Pagh, 1998).

Figure 1 represents a supply network structure of multi-tiered entities involving the formal commercial transaction and informal web of social exchanges in the supply network mimicking the true nature of a supply chain model. In Figure 1 , firms in the supply chain are pictured interacting with each other in the supply chain despite the distinct formal role of the firms such as: the raw material suppliers, distribution agencies or even the focal firms in the supply chain. Thus, it is argued that the upstream supply network now contains a mix of more formal and informal inter- 


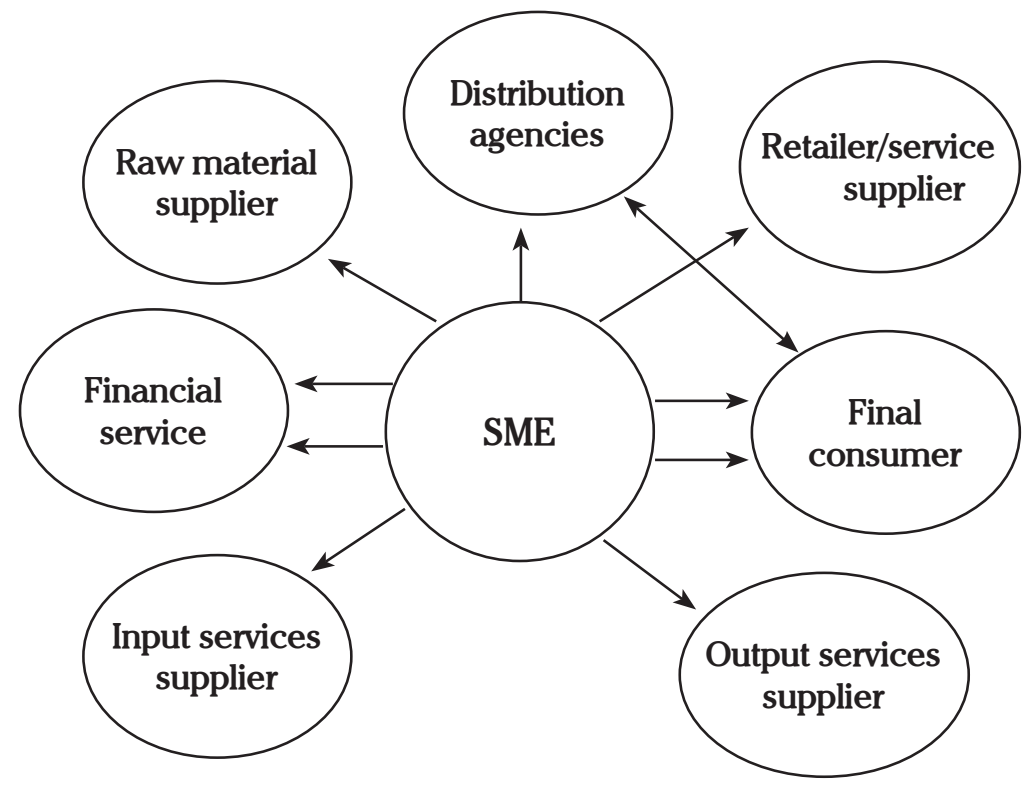

Figure 1. Supply Network Source: Ritchie and Brindley (2000)

firm relationships, thereby creating a much more complex network structure (Choi and Kim, 2008). This inevitably creates a complex structure of relationships between the entities in the supply chain. It also indicates that the supply chain has become a more complex network because of the activities and exchanges that have increased over the years.

For example, one study that attempted to map the actual map of an upstream supply network structure was conducted by Choi and Krause (2006), as well as a study by Li and Choi (2010). In 2006, Choi and Krause (2006) set off on a research project to map the actual form of a supply network structure for a component in Honda Acura in the North America manufacturing facility. The network data from this initial study was later transformed (using the Social Network Analysis tool i.e. UCINET) by Li and Choi (2010) to map the actual interaction pattern of suppliers. More specifically, the authors mapped out a full upstream supply chain structure for a simple centre console assembly for the Honda
Acura model. What developed from the research was a complex upstream supply network map of the flow of materials from the upstream suppliers to the focal firm. Choi and Kim (2008) have also pointed out the need to define the context of the buyer -supplier relationships rather than the interaction process per se. Choi and Kim (2008) draw on balance theory to stress the need for supply chain managers to adopt a strategy that pictures the firms as being involved or embedded in a larger network structure rather than existing in isolation. The authors argue that such strategy helps create a more accurate response to the market environment. Consequently, it is warranted to argue that the actions of entities in buyer-supplier relationships can only be fully elucidated in terms of the positions of these buyer-supplier organizations in the network relationships and that the position represents different impact upon the firms.

Supply Network Embeddedness. The supply network is an amalgamation of relationships or activities between firms (Croxton et al., 2001; 
Lambert and Cooper, 2000; Osman, 2015). Structurally, supply chain is virtually formed by the connectivity or links between firms where the integration progressively forms the ultimate structure, which is the supply network itself According to Choi and Kim (2008), a buyer-supplier relationship represents a dyad, or two nodes and one link, in network terms. Each node can be conceptualized as an actor performing activities for the purpose of generating value (Carter, Ellram and Tate, 2007). The firms need resources from its supplier organization, and the supplier needs contracts and payments from the buyer. On top of that the firms interact to share information regarding market opportunities and new threats (Cousins et al., 2006). As a consequence, these phenomena create a link and form a dyad or a buyer-supplier relationship. Conclusively, a buyer-supplier relationship is not only a dyad. It is also part of a network that has come to bear on individual nodes to the relationship through each other's extended business relationships. Thus, firms in the supply network are embedded in these different types of buyer-supplier relationships or simply, the supply network ties.

Embeddedness has been extensively discussed and documented in the field of economic sociology (Baum and Dutton, 1996). Sociologists have promptly indicated that the different social structure architectures in exchange relationships shape the flow of resource and subsequently, the embeddedness structure (e.g Coleman, 1988; Freeman, 1979). These distinct architectures in turn generate both constrains and opportunity for the tied organizations and can implicate the organizational performance and behaviour. Base on this viewpoint, we argue that much of the study of buyer supplier relationship in the supply chain characterized an under-socialized account of the buyer supplier organizations behaviour or actions. Within a supply network, the buyer-supplier relationship may take several forms such as contractual ties, or market transactions to informal information sharing ties (Carter, Ellram and Tate, 2007; Galaskiewicz, 2011; Kim et al., 2010; Mueller, Buergelt and Seidel-Lass, 2007). Slack, Chamber and Johnston (1995) identified these ties base on five types of organizing relationships, which include short term trade, semi and long term trade, coordinated-profit sharing, long term alliance, and joint venture. According to the authors, short-term trade refers to a formal single transaction after which the relationship ends. Semi and long-term trade agreements refer to the trade agreements without formal contracts that legally bind the organizations. Van der Vorst and Beulens (2002) view the supply chain as lying between fully vertically integrated systems and those in which the member organizations are totally independent of each other. In our opinion, the buyer supplier relationship in the supply network may take on many forms as discussed above, bounded by one extreme by formal supply network ties and at the other extreme by the informal supply network ties creating a network of interrelated and interdependent firms (Borgatti and $\mathrm{Li}$ 2010). The literature also indicated a stream of research that addresses the question of the best fit for management of the supply chain. This line of study attempts to determine the best structure or configuration of the supply network to meet the challenge of market. This stream of literature is primarily concerned with issues such as inclusion or exclusion of buyers or suppliers, mapping the structure of the supply chain, and how clusters of the buyer-supplier relationships should be managed (Cooper, Lambert and Pagh, 1997; Gilsing and Nooteboom, 2005; Powell, Koput and Smith-Doerr, 1996; Shan, Walker and Kogut, 1994). Nevertheless, to our knowledge, there is no known best configuration of buyer supplier organizations operating within the network. This issue is further complicated by the fact that the relative success of network structural configuration is predominantly related to the relational context of the buyer supplier organizations interrelatedness (Autry and Griffis, 2008; Choi and Kim, 2008). 
However, the literature falls short of addressing the importance of ascertaining the extent to which the involvement or embeddedness of these buyer-supplier organizations relates to the type of network structure and relationships. Furthermore, the focus on the organizations or the partnership as the unit of analysis and the external environment are too atomistic (Cousins et al., 2006). When evaluating potential course of actions, such assumption lacks a certain variable which equally important: the actions of other organizations or the relationships which the buyer supplier organizations are embedded in (Brookes and Singh, 2008). In addition, the themes ignore the interactive elements of the connectivity, whereby organizations obtain information from this connectivity. It is important to note that, although the buyer supplier relationship is essentially a dyadic tie between a buyer and a supplier, the outcomes and processes associated with the ties can be linked to the social network structure within which the buyer-supplier organizations are embedded in. Thus, the research question for this study is:

\section{How does the embeddedness of firms in various supply network relationships relate to their network structural positions?}

\section{METHODS}

According to Wasserman and Faust (1994), the traditional statistical method is not adept with regard to the measurement of relations. This is because the standard statistical method disavows the existence of relations between entities in a network which is itself the center of network research (Lusher, 2000). Because the focus of this study is not only concentrated on attributes of firms but also on the relations between firms, this study has consequently, adopted the social network analysis (SNA) methodology strategy for data collection and data analysis by which to obtain valid results for this study. Social network analysis is a research method which has its origins in the field of sociology, anthropology and politics (Scott, 1998; Borgatti and Li, 2010). SNA focuses on the relationships or ties between network entities, not just the attributes of the network entities (Wasserman and Faust, 1994). According to SNA scholars, a network is made up of actors who could be either individuals or organizations, which are interconnected to each other through the different kind of social interactions (Scott, 2000; Hanneman and Riddle, 2005). The interactions can be in the form of formal ties or informal ties such as contract ties, information sharing ties and referral ties (Borgatti and Li, 2010). The objective of a social network analysis is not to determine the attributes of the actors that impact upon the network, but rather on how the inter connectivity between the network actors influences network performance (Mueller, 2000).

Hence, social network analysis allows the researcher to investigate how firm are embedded in the centralized upstream supply network structure thus elucidate the true structure of supply network. A network of firms operating in an upstream supply network of a small maritime industry company formed the population of this study, i.e. the APMMHQ-1 (pseudonym provided for anonymity). The APMMHQ-1 is a manufacturing company in the Malaysian shipbuilding industry involved in ship repairs, maritime works and engineering. In network studies, all actors who are located within a pre-determined boundary are included for analysis. Consequently, unlike the conventional sampling strategy, social network analysis seeks to include all the actors in the network under consideration (Hanneman and Riddle, 2005). The sample of this study includes 37 firms involved in the production of Rigid Hull Inflatable Boats (RHIB) for APMMHQ-1. Through a network survey, data was collected from a total of 36 out of 37 firms in the APMMHQ-1 upstream supply network with an overall response rate of over 90 per cent. Network data was analyzed using network analytic techniques, namely: exploratory network analysis. Exploratory network analysis was applied to explore patterns of interactions among firms, visual analysis was applied to 
interpret the overall pattern of embeddedness of firms in the APMMHQ-1 upstream supply network. This analysis applied the spring embedding algorithm using social network software packages, i.e. UCINET (Borgatti, Everett and Freeman, 2002) NetDraw, Mage and Pajek (Nooy, Mrvar and Batagelj, 2005).

\section{RESULTS AND DISCUSSION}

Visual Analysis of the Map of APMMHQ-1 Upstream Supply Network for Product RHIB. For comparative purposes, the formal structure of the APMMHQ-1 upstream supply network for the product RHIB was first developed. Following Choi and Krausse (2006), the upstream supply network structure for the RHIB was developed based on the archival review and discussion that the researcher conducted with key informants from AMPPHQ-1. These consisted of, namely: two tiers one firms and one tier two firms concerning the flow of materials from the upstream firms to the focal firm, i.e. APMMHQ-1 for the product RHIB. Based on the data collected, the following figure depicts the upstream supply network structure of APMMHQ-1 for the supply of materials for the product RHIB. In Figure 2, the firms are coloured based on their positions in the upstream supply network structure. APMMHQ-1 is the focal firm in this centralized upstream supply network structure and its colour in red. Firms in tier one has a blue colour and consists of seven firms. Tier two firms are represented in green and consist of 16 firms. Finally, firms in tier three are purple in colour and consist of twelve firms. The structure in Figure2 indicates a hierarchical structure of the APMMHQ-1 upstream supply network for the supply of materials and services for the product RHIB. Flow of materials for the produc tion of the RHIB consists mainly of three tiers of suppliers having a total of 37 firms. The largest number of suppliers or firms in the upstream supply network structure resides in tier two of the upstream supply chain consisting of 17 firms. The logic behind this is that the firms in tier two are the firms that manufacture the raw materials from tier three firms into work in process (WIP) components or parts for the tier one supplier and, ultimately, the focal firm or manufacturer. This hierarchical structure is normally the result of the flow of resources in the APMMHQ-1 upstream supply chain network.

\section{The Upstream Supply Network of AMPPHQ-1 for the Supply of Rigid Hull Inflatable Boat (RHIB)}

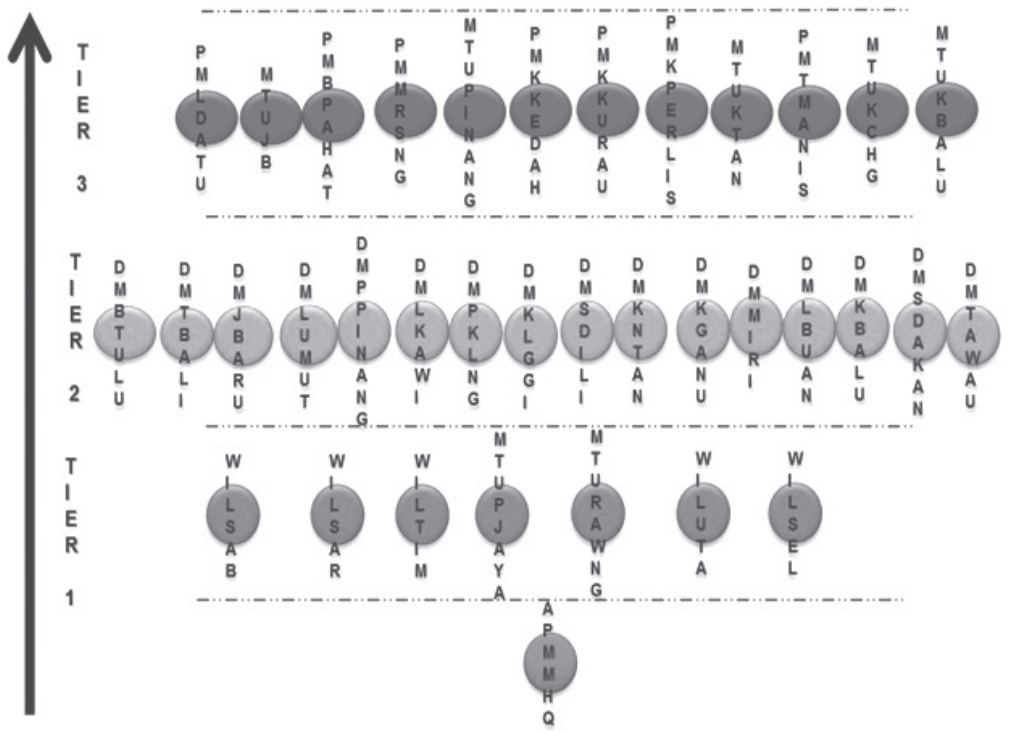

Figure 2. Upstream Supply Network Structure of APMMHQ-1 for the Product RHIB 
Visual Analysis of the Contractual Tie Network. This section presents the network maps and visual analysis of the contractual tie network generated using the NetDraw and Mage package. The figure 3 is the sociogram for the contractual tie network. In Figure 3, the researcher shows the sociogram of the contract network showing only the nodes without the ties connecting the nodes. Figure 4 shows the structure of the contract network with the nodes and ties that link the nodes in the network. Similarly, the colours of the nodes which represent the firms in the network map were coded in the same manner as in Figure 2, namely: red represents the focal firm in the upstream supply network; blue nodes are the firms in the first tier of the upstream supply network; purple nodes represent the firms in the second tier of the upstream supply network, and the green nodes represent the firms in the third tier of the APMMHQ-1 upstream supply network for the product RHIB.

Visually, in Figures 3 we see a dense central area made up of ties mainly concentrating among the APMMHQ-1, as well as other first-tier firms. The other firms are located in the outer region of the network. Firms such as WILUTA-4, WIKLSAB-31, together with APMMHQ1, appear to be centrally embedded in the network. This is an indication that in an administrative or hierarchical relationship, such as contractual relationships, the focal firms and the first-tier firms appear to be central in the network. This is because the focal firm is visible in the network structure as the firm with the most resources in terms of contracts compared with other firms in the network structure. The tier one firm are also centralized in this network map as they are similarly closely associated with the focal firm for the supply of materials for the product RHIB. This may ultimately present them with other contract relations with the focal firm. There is low connectivity between firms in the periphery structure of the contract tie network map. The need for contract relations from the APMMHQ-1 may have made the APMMHQ1 a source of contractual information by other firms. However, firms in the network map also have other contract relationships with additional firms in the network structure. These relations may involve the supply of other materials or services for the contracted firms to functions in the upstream supply network.

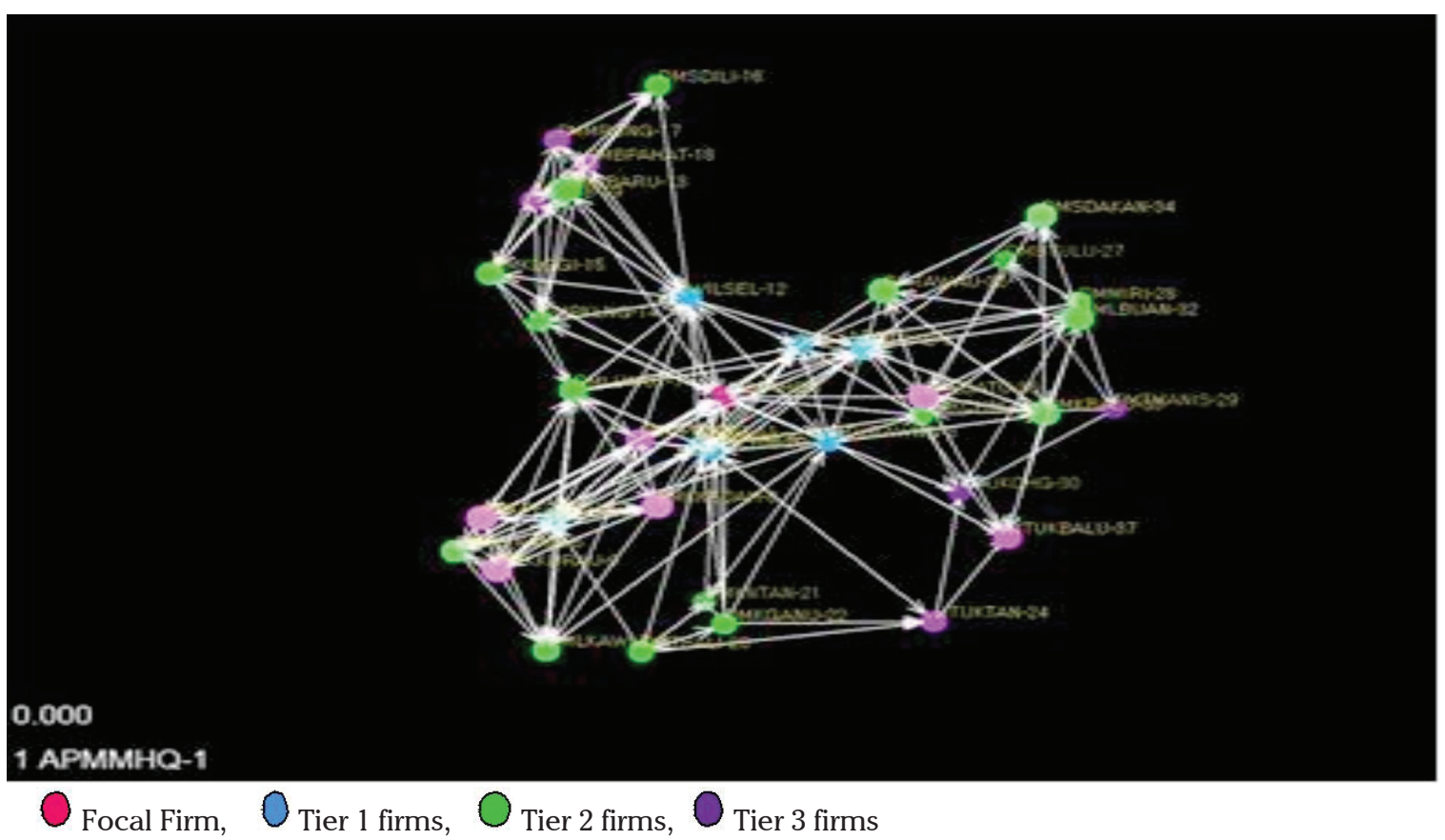

Figure 3 Network of firms based on contractual tie socio gram 
In the contractual tie network map, firms are largely situated based on their operational locations, i.e. tiers indicated by the grouping of similarly colour-coded organizations. The location of a firm in the upstream supply network tier is an unwritten indicator of the size of the firms. Accordingly, this means that, in the contract ties network map, firms are closely tied to other firms that are similar in size and capability. Overall, the network maps of the contract tie indicate that firms' connectivity are rather high, but having the focus of relations centering upon the focal and tier one firms. In addition, firms of a similar position in the upstream supply network tiers are found to be closely connected to each other through an alternative form of contract's relations.

Visual Analysis of the Information Sharing Tie Network. Figures 4 describe the pattern of interfirm relations between firms in informationsharing exchanges for the firms in the APMMHQ-1 upstream supply network structure for the product RHIB. To evaluate the pattern of connectivity of the information-sharing tie, a comparison must be made with the contract tie network structure. Visually, clearly when compared to the contract tie network structure, the information-sharing tie network structure showed a stronger level of connectivity between the firms in the APMMHQ-1 upstream supply network structure for the product RHIB. What can be the justification for these differences?

It is important to restate that, following the embeddedness theory prediction that commercial transactions are embedded in a web of social exchanges; this study posited that commercial transactions which include the contract ties that function as the administrative arm of the focal firms represent a formal means of coordination enforced upon firms in the network structure. Contractual terms and rules regulate interactions and transactions between the firms in the APMMHQ-1 upstream supply network structure. The rigid but necessary nature of the contractual relations may contribute to the occurrence of lesser ties or relations between firms in the contract tie. However, information-sharing ties represent what embeddedness theory predicts, namely, as being a form of social exchanges. Cousins et al., (2001) have stated that social exchanges such as information-sharing activities formed the informal

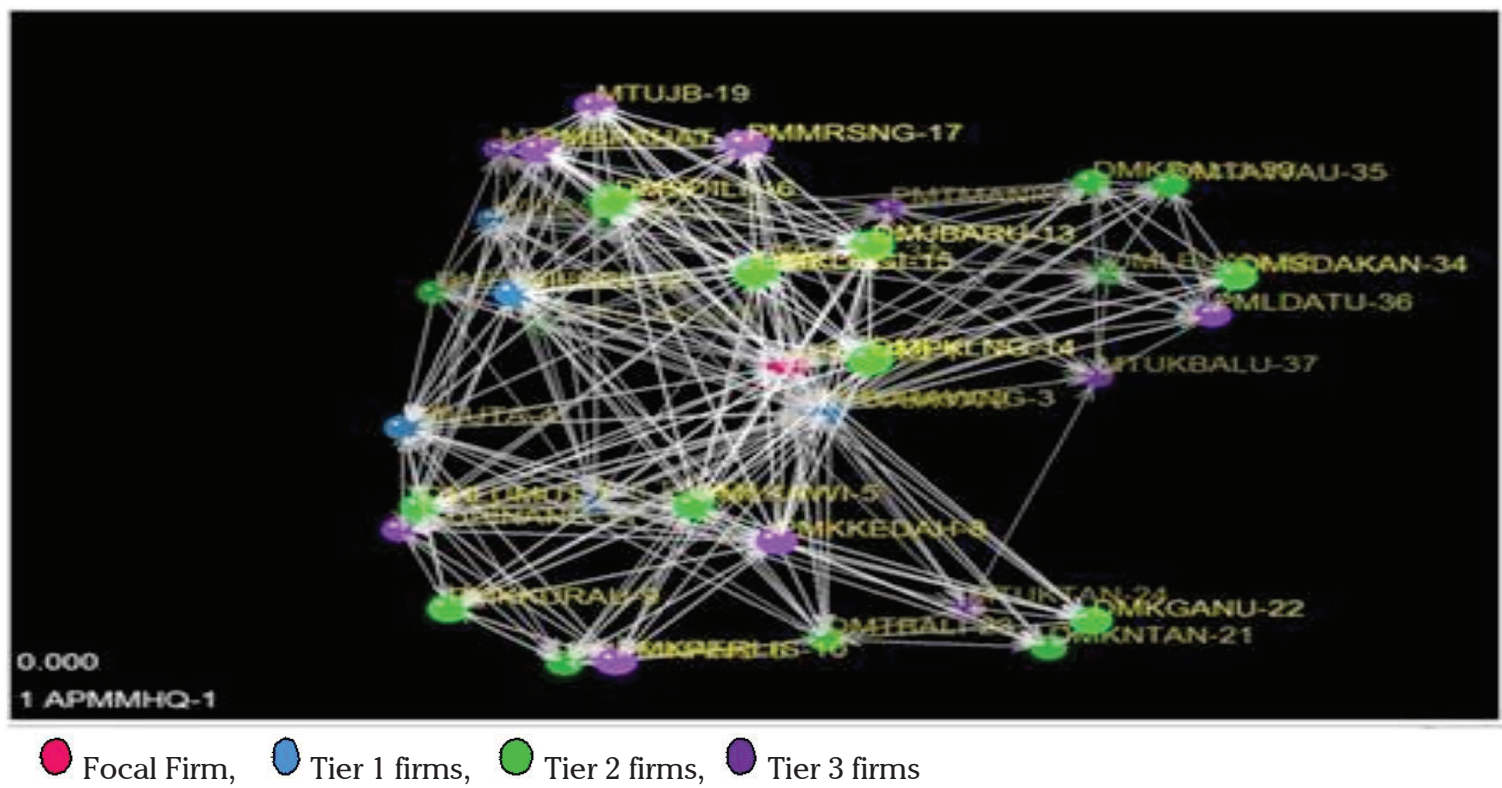

Figure 4. Network Of Firms Based On Information -Sharing Ties. Sociogram with Ties 
types of relation coordination that exist between firms in the supply network. The informal nature of the information-sharing relations between the firms means more opportunities for interactions between firms in the upstream supply network structure.

Compared to the contract tie network, the information -sharing network clearly has more ties connecting the firms. In Figure 4, we also see several dense regions in the network structure, indicating that information - sharing occurs extensively with multiple firms of the various tiers in the network. The dense central section of information-sharing tie networks is now populated by a mix of first tier and second tier firms, as well as the focal firm at the central node. Figure 4 shows that firms such as APMMHQ1, WILUTA4, WILSAB31, and DMPKLANG -14 are centrally embedded in the social network. Furthermore, the sociogram indicated that, in the informationsharing network, firms are communicating among themselves despite the different tiers. This can be seen from the sociogram where buyer organizations such as PMTMANIS29, DMTBALI23, WILTIM20, and WILUTA4 are quite embedded in the network structure along with other firms from other tiers. Such conditions have happened as per the nature of information-sharing ties, which are rather less formal than contractual ties; for example, encouraging organizations to look outside their comfort zone for information.

Visual Analysis of the Referral Made Tie Network. Figures 5 display the sociogram for a referral made tie network. Again, for the visual analysis, the researcher made a optical comparison of the pattern of connectivity between firms in the referral made tie, information-sharing tie and contract tie respectively. In this study, referral activities are considered relationships that sit in the middle of the for mal and informal continuum (as some referral activities are part of contractual requirements, as well as informal communications activities). The visual analysis of the sociogram indicated the following. Compared to the information- sharing tie network and the contract tie network structure, the network map or sociogram of the referral made tie indicate that the patterns of relations between firms are lesser compared with the informationsharing tie, however, considerably more than the contract tie. The dense central section of referral made tie network is occupied by the APMMHQ-1.

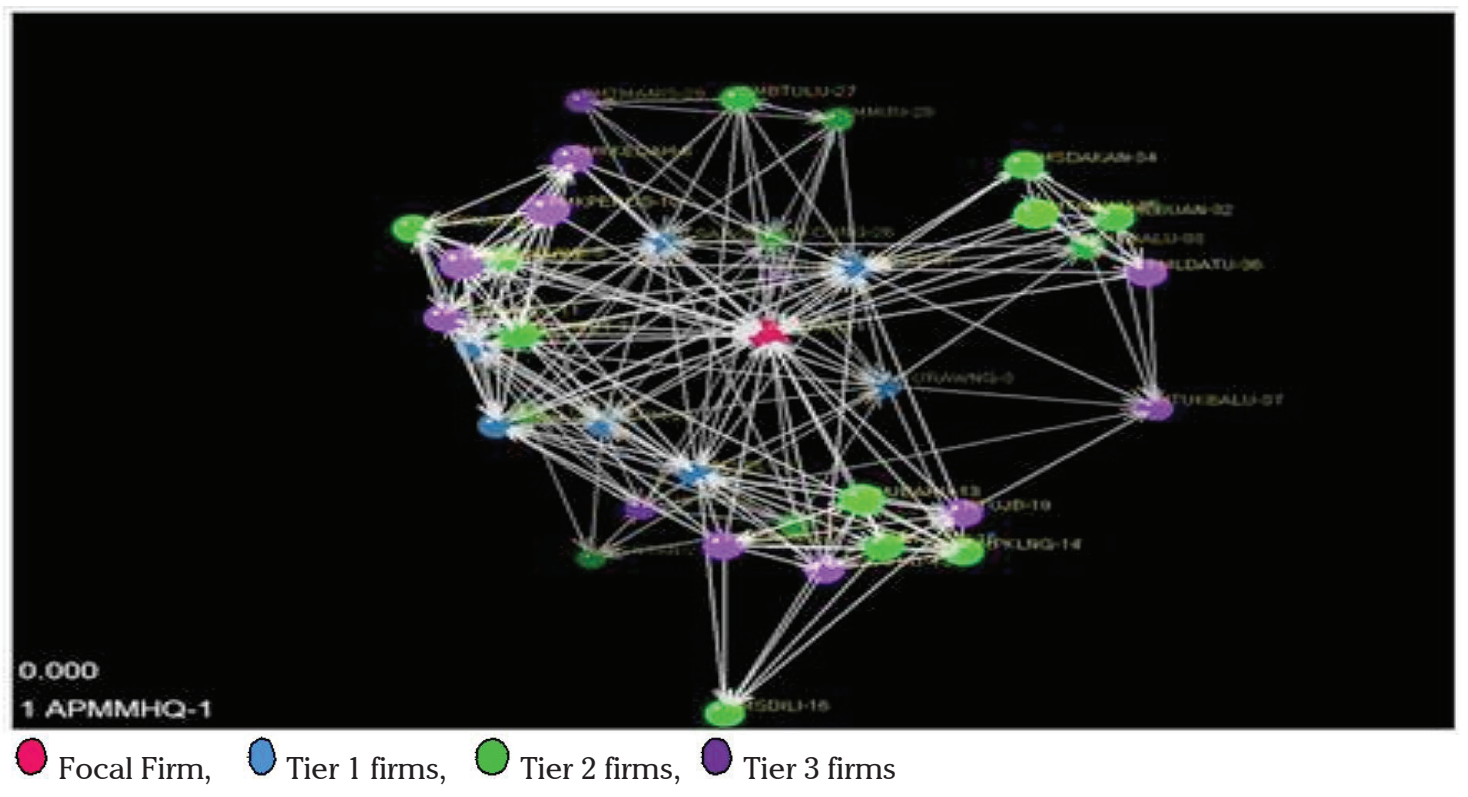

Figure 5. Network Of Firms Based On Referral Made Tie. Sociogram with Ties 
Figure 5 also indicates from the network plot that, in the referral made tie network WILSAB31, WILUTA4, WILSA25, and WILTIM20 are centrally embedded in the outer ring of the network central location. The sociogram also indicated that, in the referral made network, firms are embedded into a number of clusters. We could see this from the grouping of several forms into sub-groups in the referral made network as indicated in Figures 5. For example, the network maps show a cluster of MTUJBARU-13, DMPKLNG-14, PMBPAHAT-18, PMMRSNG-17, DMKGANU-22, and DMPKLNG-15. This heavy clustering of firms in the AMPPHQ-1 upstream supply network structure could be related to the nature of referral activities that mostly centre or focus upon other network members who are physically closer than the "farfetched" connections.

In this study, in order to guide the analysis of the network maps, the researcher argues in favor of Cousins et al. (2006). The authors argue that interfirm relations in the supply chain can be classified into formal and informal types of relations depending on the type of coordination involved in overseeing these inter-firm relations. Relations that are based on terms and written guidelines as the coordination mechanism are classified as being a formal form of inter-firm relations. On the other hand, relations that are formed voluntarily and are not bounded by the rigidity of rules in its coordination mechanisms are classified as the informal form of relations. Thus, the contract ties can be identified as being the formal form of relations as they are based on the contractual terms and requirements; while the informationsharing tie is a form of informal relations due to its being voluntary and not bound by any written conditions. Referral actitivities may sometimes involve performing referral duties as required in a contract, such as sending staff for training. They may also include voluntary referral activities, such as sending or seeking price information. Consequently, referral actitivies are considered as being in the middle of the formal and informal continuum of inter-firm relations in the centralized upstream supply network.

First, the visual analysis performed showed that, in the more formal relationships, the core nodes or central firms with high numbers of tie connections are largely the focal firms and the first-tier firms. On the other hand, the optical analysis of the sociogram for the informal information sharing ties shows that the network structure differed. The differences again centred on the type of firms that received the most ties or connectivity. In the informal information-sharing tie network structure, there is a mix of firms from distinctive tiers that are central in the network. The researcher argues that this distinct network structural formation relates to the type of resources offered by the different kind connectivity. This is rightly so, as the distinctive type of ties may offer the connected organizations with distinct social capital (Cousins et al., 2006; Gordon, Kogut and Shan, 1997) of competitive advantage (Porter, 1985; 1998). Our finding is similar to Oh et al. (2004). They documented that the configuration of group members' social relationships is related to the construct of the group social capital that is inherent in the structure or pattern of relations between actors (Burt,1995; 1995; Coleman, 1988; Nahapiet and Ghoshal, 1998). This pattern of connection creates a network of interdependent social exchanges. Consequently, organizations with the right connections occupy a position in the network of social exchanges that allows them to bring their resources to bear on problems in a more timely and effective manner (Burt, 2004).

Secondly, the network maps show that firms are more connected in the informal network structure than they are in the formal network of relations. This is indicated by the pattern of connectivity between firms in the upstream supply network structure. As we see in Figures 3 and 4, there are more lines connecting the firms' in. the information-sharing tie network than in the contract tie network. Such pattern of connectivity is an indication that firms are more connected in the informal network 
structure than in the formal network structure.

\section{MANAGERIAL IMPLICATIONS}

Achieving success in a inter-organizational network is essential. Understanding how and why some business relationships succeed and why others fail is perhaps among the most critical issues facing firms in the supply network. Thus, from a manager's standpoint, it is important to know how to improve firms' overall performance. Based on the findings of this research, the following implications are highlighted: firms' involvement with others in the network differs depending on the type of interorganizational relations; the findings can become the barometer of involvement for firms to optimize involvement resources and creation of relational capital outcomes, partnership evaluation and forecasting strategy respectively.

\section{CONCLUSION}

Combining the results of the network socio-gram, it indicate that in informally integrated ties, firms are more involved or embedded in the informal network structure than in formal ones. Thus, this would suggest that firms' network structural positions in the centralized upstream supply network differ based on the different types of interfirm relations. Therefore, in answering research question, it is clear from the exploratory network analysis, that in the centralized upstream supply network structure, firms are more embedded or involved in a network of $r$ elations that requires less formal coordination than in a formal network of relations.

What this answer also indicates is that, in the centralized upstream supply network structure, both the formal relationships and informal relationships co-exist. This can inadvertently mean the presence of both the formal and informal forms of management or coordination approaches to inter-firm relationship management. Thus, practically, the ideal strategy of management goals of inter-firm relations complexity may be achieved by the application of the formal and informal coordination strategies at the inter-firm level. Thus, this could lead to the creation of a heterogeneous form of the firm. The heterogeneous structure is useful, because of the synergy of both the formal and informal structures of the network. The formal structure provides increased control, coordination and responsibility; while the informal network increases confidence, flexibility and responsiveness. Conceptualizations of organizational forms have focused on the market, hierarchy and networks (Powell, 2003). However, researchers have argued that the three different types of organization form can be combined into a more synergistic plural. For example, in the field of organizational studies, Adler (2001) found a mix of informal and formal mechanisms when managers attend to issues of business management. This research suggests a mix of formal and informal coordination mechanisms in business arrangements in the context of supply networks. The combination of formal and informal relations in the supply network can be a new addition to the mode or form of organization in the context of supply chain management.

In summary, while answering research question of this study, the researcher found that, in the context of the upstream supply network structure, firms' embeddedness or involvement is contingent upon the type of network relations. Clearly, the exploratory network analysis has given a strong indication that, in the centralized upstream supply network structure, more attention and resources (as forming new alliances requires time and even money) of the embedded firms are dedicated to informal networks of relations than to the formal ones. Through the utilization of exploratory network of the four firms' relationships, i.e.: contract ties, information- sharing, reference and made reference received tie; it is clear that the network embeddedness of firms in the supply network is related to the nature of the type of ties or firm relationships that are being considered. The findings of the exploratory network analysis indicated that, in a more formal form of firms' 
relationships; such as the contract tie, the firms are less embedded in the network structure. However, in the less formal ties or firm relationships (such as the information-sharing ties), firms are more embedded in their network structure as indicated by the dense number of ties. More importantly, because the definition of embeddedness relates to the degree of involvement of firms in the firm's relationship, this finding suggests that firms are less involved within the network of formal ties compared to the informal inter-firm relations.

The significant of this study is twofold. Through our findings, this study found similar conditions in the upstream supply network, where firms are embedded in contract ties, information-sharing, referral made and referral received ties respectively. In addition, this study also went a step further by classifying these inter -firm relations into the formal and informal nature of its coordinations. The results indicate that, in the upstream supply chain, firms having inter-firm relationships are more embedded in the informal network of inter-firm relationships than in the formal inter-firm relations (Uzzi, 1997). Although this finding contradicts the work of Granovetter (1985) (which argues that the strength of tie's influences actor embeddedness in networks), our finding is in line with the work of Uzzi (1997) who found that in inter-firm networks, firms are embedded in arms-length (formal relations) type of ties and embedded ties (informal relations).

\section{REFERENCES}

Borgatti \& Li (2009), 'On Social Network Analysis in a Supply Chain Context*', Journal of Supply Chain Management, vol. 45, no. 2 , pp. $5-22$.

Borgatti, S \& Molina, J (2003), 'Ethical and strategic issues in organizational social network analysis', The Journal of Applied Behavioral Science, vol. 39, no. 3, p. 337.

Borgatti, SP, Jones, C \& Everett, MG (1998), 'Network measures of social capital', Semantic Pajek Networks Software, vol. 21, no. 2, pp. 27-36.

Choi \& Kim, Y (2008), 'Structural Embeddedness And Supplier Management: A Network Perspective', Journal of Supply Chain Management, vol. 44, no. 4, pp. 5-13.

Choi \& Krause (2006), 'The supply base and its complexity: Implications for transaction costs, risks, responsiveness, and innovation', Journal of Operations Management, vol. 24, no. 5, pp. 637-52.

Coleman, JS (1988), 'Social Capital in the Creation of Human Capital', American journal of sociology, vol. 94, no. ArticleType: research-article / Issue Title: Supplement: Organizations and Institutions: Sociological and Economic Approaches to the Analysis of Social Structure / Full publication date: 1988 / Copyright ( 1988 The University of Chicago Press, pp. S95-S120.

Corteville, L \& Sun, M (2009), An interorganizational social network analysis of the Michigan diabetes outreach networks: Measuring relationships in community networks, Lansing, MI: Michigan Department of Community Health.

Ford, EW, Wells, R \& Bailey, B (2004), 'Sustainable network advantages: A game theoretic approach to community-based health care coalitions', Health Care Management Review, vol. 29, no. 2, p. 159.

Freeman, LC 1979, 'Centrality in social networks conceptual clarification', Social Networks, vol. 1, no. 3, pp. 215-39.

Granovetter (1985), 'Economic action and social structure: the problem of embeddedness', American journal of sociology, pp. 481-510.

Granovetter, M (1985), 'Economic action and social structure: the problem of embeddedness'.

Gulati, R (1995), 'Does Familiarity Breed Trust? The Implications of Repeated Ties for Contractual Choice in Alliances', The Academy of Management Journal, vol. 38, no. 1, pp. 85-112.

Gulati, R \& Gargiulo, M (1999), 'Where do interorganizational networks come from?', American journal of sociology, vol. 104, no. 5, pp. 1439-93. 
Gulati, R \& Gargiulo, M (1999), 'Where do interorganizational networks come from?', American journal of sociology, vol. 104, no. 5 , pp. $1398-438$

Knoke, D \& Kuklinski, J (1982), Network analysis, Sage Publications, Inc.

Krackhardt, D (1999), 'The ties that torture: Simmelian tie analysis in organizations', Research in the Sociology of Organizations, vol. 16, no. 1999, pp. 183-210.

Krauss, M, Mueller, N \& Luke, D (2004), 'Interorganizational relationships within state tobacco control networks: a social network analysis', Preventing Chronic Disease, vol. 1, no. 4, p. A08.

Lusher, D (2011), 'Masculinity, educational achievement and social status: a social network analysis', Gender and Education, vol. 23 , no. 6 , pp. 655-75.

Lusher, D \& Robins, G (2010), 'A social network analysis of hegemonic and other masculinities', The Journal of Men's Studies, vol. 18 , no. 1, pp. 22-44.

Lusher, D, Robins, G \& Kremer, P (2010), 'The application of social network analysis to team sports', Measurement in physical education and exercise science, vol. 14, no. 4, pp. 211-24.

McEvily, B, Perrone, V \& Zaheer, A (2003), 'Trust as an organizing principle', Organization Science, pp. 91-103. McEvily, B \& Zaheer, A (1999), 'Bridging ties: a source of firm heterogeneity in competitive capabilities', Strategic Management Journal, vol. 20, no. 12, pp. 1133-56.

Osman, L. H., Ahmad, A., \& Omar, N. A. (2015) Analyzing the impact of firm's embeddedness in a centralized supply network structure on relational capital outcomes. review of economic and business studies, 55.

Osman, L. H. (2015). A social network model of supply chain management in formal and informal inter-firm engagement. LogForum, 11(4).

Podolny, JM \& Page, KL (1998), 'Network forms of organization', Annual review of sociology, pp. 57-76. Powell, W (1996), 'Neither market nor hierarchy: network forms of organization', in Te al (ed.), Markets, Hierarchies and Networks Understanding Governance RAW Rhodes,, Buckingham, Open University Press, vol. , pp. 265-76. 29 ... 35

Reagans, R, Zuckerman, E \& McEvily, B (2004), 'How to make the team: Social networks vs. demography as criteria for designing effective teams', Administrative Science Quarterly, vol. 49, no. 1, pp. 101-33.

Robins, G, Pattison, P, Kalish, Y \& Lusher, D (2007), 'An introduction to exponential random graph models for social networks', Social Networks, vol. 29, no. 2, pp. 173-91.

Robins, G, Pattison, P \& Wang, P (2009), 'Closure, connectivity and degree distributions: Exponential random graph (p*) models for directed social networks', Social Networks, vol. 31, no. 2, pp. 105-17.

Scott, J (1988), 'Social network analysis', Sociology, vol. 22, no. 1, p. 109.

Uzzi, B (1997), 'Social Structure and Competition in Interfirm Networks: The Paradox of Embeddedness', Administrative science quarterly, vol. 42, no. 1, pp. 35-67.

Wang, P, Robins, G \& Pattison, P (2006a), 'Pnet: a program for the simulation and estimation of exponential random graph models', University of Melbourne.

---- 2006b, 'PNet: Program for the estimation and simulation of p* exponential random graph models, User Manual', Department of Psychology, University of Melbourne.

Womack, JP (1990), Machine that changed the world, Scribner.

Wu, Z, Choi, TY \& Rungtusanatham, MJ (2010), 'Supplier-supplier relationships in buyer-supplier-supplier triads: Implications for supplier performance', Journal of Operations Management, vol. 28, no. 2, pp. 115-23. 